\title{
On the uniform motion of water, both in small canals and trenches and in streams and rivers
}

\section{Hagen}

To cite this article: M. Hagen (1876) On the uniform motion of water, both in small canals and trenches and in streams and rivers, Philosophical Magazine Series 5, 2:10, 239-239, DOI: $10.1080 / 14786447608639098$

To link to this article: http://dx.doi.org/10.1080/14786447608639098

曲 Published online: 13 May 2009.

Submit your article to this journal $\lceil\pi$

Џ Article views: 2

Q View related articles $\widetilde{ }$ 
ON THE UNIFORM MOTION OF WATER, BOTH IN SMALL CANALS AND TRENCHES AND IN STREAMS AND RIVERS. BY M. HAGEN.

For the former the observations of Darcy and Bazin on the inlets and outlets of the Bourgogne canal, and for the latter those of Humphreys and Abbott on some of the great rivers of America were taken as a basis. Introducing the simple law

$$
c=k \cdot a^{x} \tau^{z}
$$

where $c$ signifies the mean velocity, $\alpha$ the relative fall, and $r$ the mean radius (that is, the quotient obtained by dividing the area of the cross section by the liquid periphery), and employing the method of least squares, gave, after comparison with various other measurements :-

$$
\begin{aligned}
& \text { For trenches, } c=4 \cdot 9 . \tau \alpha^{\frac{1}{5}} ; \\
& \text { For rivers, } \quad c=6 . \tau^{\frac{1}{2}} \alpha \frac{1}{5} .
\end{aligned}
$$

The numerical coefficient holds in the first case for any measure whatever; but in the second it holds for English and Rhenish measurement in feet, while for metres it changes into 3.34 .

As soon as $r=1.5$ foot or $=0.47$ metre, both expressions give the same result; at this point, therefore, there is a transition from the one law to the other.-Monatsbericht der k. preussischen Akademie der Wissenschaften zu Berlin, 1876, p. 243.

\section{A GLASS CIRCLE FOR THE MEASUREMENT OF ANGLES. BY LEWIS M. RUTHERFURD.}

At the summer meeting of the National Academy of Sciences in the year 1866, I described the micrometer which I had constructed for the measurement of astronomical photographs. It was capable of measuring angles of position, and also distances in directions at right angles to each other. These last measurements were made by aid of screws arranged after the manner of those of an ordinary slide rest: these screws were constructed with great care; and I had good reason to be satisfied with the smallness of their errors.

At the spring meeting of the Academy for the year 1870, I explained that I had been obliged to give up the idea of using screws on account of the rapid changes in their errors caused by friction and consequent wear; and I then stated that I intended" to discard the screw and the compressed slide, and substitute for them a divided glass scale, to be read by a micrometer-microscope, and a gravity-slide with one $V$ and one flat slide. This intention I carried out during the year, the new form being first used about the month of March 1871 . It has been constantly used since that time, and continues to give great satisfaction. The success of this divided glass scale confirmed me in a determination of long standing, to try the experiment of substituting a glass circle for one of metal in some instrument for the measure of angles of precision.

Two years' absence in Europe and other occupations conspired to postpone the execution of this plan until the past winter, during which it has been realized with what seems to me the most pro- 